\title{
Longevity of Controlled-release Fertilizer Influences the Growth of Bedding Impatiens
}

\author{
Gladys A. Andiru ${ }^{1,2}$, Claudio C. Pasian², Jonathan M. Frantz ${ }^{3,4}$, \\ and Pablo Jourdan ${ }^{2}$
}

AdDITIONAL INDEX wORDs. Impatiens wallevana, slow-release fertilizers, fertilization, bedding plants, application rate, consumer evaluations

Summary. Controlled-release fertilizers (CRFs) have not been extensively used in floricultural production, perhaps due to lack of grower experience and researchbased information with their use in herbaceous plant production. Any information about the correct use of CRF should increase growers' confidence in using this type of fertilizer. The objective of this research was to compare the growth and quality of bedding impatiens (Impatiens wallevana XTREME ${ }^{\mathrm{TM}}$ 'Scarlet') when grown with typical water-soluble fertilizer (WSF) and with different combinations of longevity and rates of a single formulation of CRF. The CRF $16 \mathrm{~N}-3.9 \mathrm{P}-10 \mathrm{~K}$ consisted of different longevities (3-4, 5-6, 8-9, or 12-14 months) and application rates (1.4, $3.4,6.8,10.2$, or $\left.13.6 \mathrm{~kg} \cdot \mathrm{m}^{-3}\right)$. Plants were grown in the greenhouse, and consumer evaluations were performed at market maturity. Plant canopy cover, flower cover (FC), and shoot dry weight (DW) were also determined. Commercially acceptable plant quality was achieved with CRF application rates between 3.4 and $6.8 \mathrm{~kg} \cdot \mathrm{m}^{-3}$. At low CRF application rates, the faster release rate (shorter longevities) CRFs produced larger plants [DW and leaf canopy cover (LCC)] with greater flowering potential (FC) than slower release rate CRFs. At higher application rates, slower release rates (longer longevities) outperformed the faster release CRFs for the same parameters. CRF-grown plants were smaller than WSF plants when CRFs were applied at the lowest rates. No differences in any of the three variables measured were found when plants were grown at a rate of $6.8 \mathrm{~kg} \cdot \mathrm{m}^{-3} \mathrm{CRF}$ of any longevity or with WSF. Growers should adjust CRF application rates according to CRF longevity.

$\mathrm{U}$ sing CRF instead of WSF for container-grown plant production is thought to limit nutrient loss (Haver and Schuch, 1996; Medina et al., 2008). CRFs have been identified as a best management practice because they supply small amounts of localized nutrients to the surrounding substrates over a period of time (Cabrera, 1997; Colangelo and Brand, 2001; Simonne and Hutchinson, 2005). The use of CRFs may be effective at reducing nutrient runoff

Funding for this research was provided by the Cooperative State Research, Education and Extension Services (CSREES), U.S. Department of Agriculture (USDA). Greenhouse, Ohio project. Award \# 200938897-19894). Salaries and research support were provided in part by state and federal funds appropriated to the Ohio Agricultural Research and Development Center (OARDC), the Ohio State University.

We thank Everris (formerly The Scotts Company) for supplying the fertilizers used in this research.

Mention of trade names implies no endorsement by the authors.

${ }^{1}$ Former Graduate Student

${ }^{2}$ Department of Horticulture and Crop Science, The Ohio State University, Columbus, OH 43210

${ }^{3}$ USDA-ARS, 2801 West Bancroft, Mail Stop 604, Toledo, $\mathrm{OH} 43606$

${ }^{4}$ Corresponding author. E-mail: jonathanfrantz319@ gmail.com and improving nutrient use efficiency (Andiru et al., 2011; Cabrera, 1997; Klock-Moore and Broschat, 1999; Wright, 1992) in addition to improving plant quality (Shaviv, 2001) in floriculture greenhouse production. The increasing need to incorporate more sustainable production systems in the green industry has led to more research on the use of CRFs for bedding plant production. However, CRF use alone does not provide a complete solution to the problem of nutrient leaching, but it can help address a number of grower needs to apply the right fertilizer, at the right time, at the right rate, and at the right location. Appropriate application methods and CRF types must be calibrated to match crop production (Broschat and Klock-Moore, 2001).

The nursery and greenhouse industries account for $\approx 20 \%$ of total CRF use in the United States (Merhaut et al., 2006). Although the nursery industry has used CRFs extensively in containerized woody ornamental production, its use in floricultural production has been limited. Anecdotal information suggests that exceptions to this trend are in the production of stock plants, garden chrysanthemum (Chrysanthemum $\times$ morifolium) and poinsettia (Euphorbia pulcherrima), where CRF and WSF use is integrated. Limited research-based information and experience appear to limit commercial CRF use in floricultural production. The risk of plant damage because of salt accumulation at high CRF application rates may also be at work. Some growers fear the loss of control over their fertilization programs and with it the ability to "tone" crops, i.e., withholding nutrients before shipment or sale, to meet production goals (Hulme, 2006).

Different CRF formulations and longevities have been developed to meet the variable nutritional requirements of different plants (Hulme and Buchheit, 2007). CRFs that release nutrients during different time periods [e.g., 3- to 4-month (brief longevity), 12- to 14-month (extended longevity)] are available. The ideal CRF for greenhouse production will depend on the crop and its production time. Depending on the crop, CRF longevity should correspond to the time of production and plant nutrient uptake to increase growth, quality, and reduce nutrient waste (Hulme and Buchheit, 2007; Ivy et al., 2002; Nelson, 1991; Shaviv, 2001; Wright, 1992). Still, for

\begin{tabular}{llll}
\hline $\begin{array}{l}\text { Units } \\
\text { To convert U.S. to SI, } \\
\text { multiply by }\end{array}$ & U.S. unit & SI unit & $\begin{array}{l}\text { To convert SI to U.S., } \\
\text { multiply by }\end{array}$ \\
\hline 29.5735 & $\mathrm{fl} \mathrm{oz}$ & $\mathrm{mL}$ & 0.0338 \\
7.8125 & $\mathrm{fl} \mathrm{oz} / \mathrm{gal}$ & $\mathrm{mL} \cdot \mathrm{L}^{-1}$ & 0.1280 \\
3.7854 & $\mathrm{gal}$ & $\mathrm{L}$ & 0.2642 \\
2.54 & inch $(\mathrm{es})$ & $\mathrm{cm}$ & 0.3937 \\
6.4516 & inch & $\mathrm{cm}$ & 0.1550 \\
0.5933 & $\mathrm{lb} / \mathrm{yard}$ & $\mathrm{kg} \cdot \mathrm{m}^{-3}$ & 1.6856 \\
1 & $\mathrm{mmho} / \mathrm{cm}$ & $\mathrm{mS} \cdot \mathrm{cm}^{-1}$ & 1 \\
28.3495 & $\mathrm{oz}$ & $\mathrm{g}$ & 0.0353 \\
1 & $\mathrm{ppm}$ & $\mathrm{mg} \cdot \mathrm{L}^{-1}$ & 1 \\
$\left({ }^{\circ} \mathrm{F}-32\right) \div 1.8$ & ${ }^{\circ} \mathrm{F}$ & ${ }^{\circ} \mathrm{C}$ & $\left({ }^{\circ} \mathrm{C} \times 1.8\right)+32$ \\
& & &
\end{tabular}


most greenhouse crops, 3-month longevity CRFs are the most commonly recommended and used (Nelson, 1991). Documentation of the effects of CRF longevity on bedding plant crops is lacking. Providing such information will enable growers to decide what CRF type and longevity would be the most appropriate. The objective of this research was to determine the effects of CRF of different longevities incorporated at different rates on the growth and quality of impatiens.

\section{Materials and methods}

Plugs of impatiens XTREMETM 'Scarlet' were obtained from a commercial producer (Green Circle Growers, Oberlin, $\mathrm{OH}$ ) and planted in a substrate consisting of a $3: 1$ (by volume) ratio of canadian sphagnum peatmoss (Sunshine Peat Moss; Sun Gro Horticulture, Bellevue, WA) and perlite (Therm-ORock East, New Eagle, PA). A total of $3 \mathrm{~kg} \cdot \mathrm{m}^{-3}$ carbonated lime was added to correct the $\mathrm{pH}$ to $5.8-6.4$. This substrate was hydrated with tap water containing $\mathrm{l} \mathrm{fl} \mathrm{oz} / \mathrm{gal}$ of the surfactant Aqua-Gro L (Scotts Company, Marysville, $\mathrm{OH}$ ) per liter. Up to $5 \mathrm{~L}$ of water was added to reach $30 \%$ to $50 \%$ container capacity moisture content (Argo and Biernbaum, 1996). The substrate was then placed in a $100-\mathrm{L}$ plastic container and left to equilibrate for $24 \mathrm{~h}$. Before incorporating the CRFs and planting the plugs, substrate electrical conductivity (EC) and $\mathrm{pH}$ were measured using a $1: 2$ dilution method (Cavins et al., 2001) with a $\mathrm{pH}$ and EC meter (Accumet model AP85 pH/conductivity meter; Fisher Scientific, Pittsburgh, PA). Each $4 \times$ 3.4 -inch plastic container $(770 \mathrm{~mL})$ was filled with the substrate plus CRF incorporated and immediately planted with one impatiens plug.

The CRF used in the experiments was a $16 \mathrm{~N}-3.9 \mathrm{P}-10 \mathrm{~K}$ formulation (Osmocote Plus; Everris International, Geldermalsen, The Netherlands), whereas the WSF was a $20 \mathrm{~N}-4.4 \mathrm{P}-16.6 \mathrm{~K}$ formulation (Peters Professional, Everris International). The CRFs were engineered to release nutrients over time periods of $3-4,5-6,8-9$, or $12-14$ months at $70{ }^{\circ} \mathrm{F}$. CRFs were incorporated into the substrate at rates of 1.4 , $3.4,6.8,10.2$, or $13.6 \mathrm{~kg} \cdot \mathrm{m}^{-3}(1,2.5$, $5,7.5$, or $10 \mathrm{~g}$ per container, respectively). A WSF solution of $150 \mathrm{ppm}$ nitrogen concentration in tap water $\left(\mathrm{EC}<1.0 \mathrm{mS} \cdot \mathrm{cm}^{-1}\right.$, tap water alkalinity
$<90.0$ ppm) was applied either in discrete amounts, using the same volume of water applied to CRF treatments (WSF-1) or using a hose without measuring the volume applied (WSF-2), which is a common irrigation method used by growers. Plants were monitored daily, and irrigation with tap water was supplied as needed depending on plant size and environmental conditions. Plants grown with CRF were irrigated with a measured volume of water (to yield a $20 \%$ to $30 \%$ leaching fraction).

The experiments consisted of factorial arrangements of four CRF longevities by five rates plus WSF-1 and WSF- $2(4 \times 5+2$ factorial arrangement). All treatments were arranged in a randomized complete block design with six blocks. Each block represented one replication with one plant per treatment within each block.

The experiment was repeated in time in a greenhouse with a double layer acrylic roof at the Ohio State University (Columbus). Greenhouse temperatures and outside radiation levels were obtained from the greenhouse computer environmental control and weather station (Argus Control Systems, White Rock, BC, Canada) for both experiments. In Expt. 1, plants were grown for $54 \mathrm{~d}$ (16 Oct. to 11 Dec.) with low and high temperature set points of 18 and $21^{\circ} \mathrm{C}$, respectively. The average outdoor daily light integral (DLI) during the production period was $6.5 \mathrm{~mol} \cdot \mathrm{m}^{-2} \cdot \mathrm{d}^{-1}$. Expt. 2 was a repetition of Expt. 1 with the exception that plants were grown for $42 \mathrm{~d}$ (7 Aug. to 18 Sept.). The greenhouse low and high temperature set points were 18 and $21^{\circ} \mathrm{C}$, respectively, and the average outdoor DLI was $18.2 \mathrm{~mol} \cdot \mathrm{m}^{-2} \cdot \mathrm{d}^{-1}$. Periodically during growth, substrate EC and $\mathrm{pH}$ were measured using the pour-through method (Cavins et al., 2001) of a single replicate plant from each treatment. Because measurements at each treatment were not replicated, the data were not analyzed statistically and are reported only for the sake of discussion.

Consumer evaluations were conducted by a group of 40 (Expt. 1) and 35 (Expt. 2) people. Each panel of evaluators consisted of growers, master gardeners, faculty, staff, and horticulture students. Plants were rated on a scale of 1 to 5 , where ratings of 1 and 5 indicated dislike and like very much, respectively.
At the end of each experiment, following a technique similar to the one used by Bumgarner et al. (2012), pictures of the plant canopies with all flowers first and then without the flowers were taken from above with a digital camera (EX-Z250A; Casio, Higashine, Japan). A tripod was placed at a fixed position holding the camera $\mathrm{l} \mathrm{m}$ aboveground with the objective lens looking down. A mark was made on the ground, and each plant was placed on the mark to ensure uniformity under the focus of the camera. Pictures were then analyzed with digital analysis software (Assess Image Analysis; APS Press, St. Paul, MN) to measure the exposed leaf area (green) called here "leaf canopy cover" and the exposed area covered by flowers called here "flower cover," both in square centimeters. This software works on the principle of matching surfaces where the user sets threshold boundaries (color) and the software automatically selects that color range from the original color image (Lamari, 2002). The software fills in the areas that have the pixel value within the range specified. Once an image is filled in, data for the measurements (LCC or FC) can be obtained. LCC was used as an estimate of plant spread (e.g., plant diameter) and FC as a proxy for number of flowers per plant.

Aboveground plant parts were harvested, placed in separate bags, and left to dry in a forced-air oven (GS Blue $\mathrm{M}$ Electric, New Columbia, PA) at $55^{\circ} \mathrm{C}$ for $48 \mathrm{~h}$. Plant DW was measured, and along with LCC, FC and consumer ratings were analyzed with linear regression against fertilizer rate using the regression procedure of SigmaPlot (version 12; Systat Software, San Jose, CA).

If regressions were significant, the best fit was determined using the $R^{2}$. Predicted maximum DWs were calculated by substituting the value of maximum CRF rate in the regression equation. Differences within fertilizer rates, LCC, FC, and consumer ratings were analyzed using the analysis of variance procedure of statistical software (SAS version 9.2; SAS Institute, Cary, NC). Means were separated using Fisher's least significant difference at $P \leq 0.05$. Data were tested for normality before analysis.

\section{Results}

EXPT. 1. Initial substrate $\mathrm{pH}$ was 6.2 , which is within the required $\mathrm{pH}$ 
range of 5.5-6.4 (Argo and Biernbaum, 1996), and initial EC was $0.68 \mathrm{dS} \cdot \mathrm{m}^{-1}$. At the time of harvest, clear visual differences among treatments were evident. The most obvious was the stunting of plants at the lowest application rate. Shoot DW as a function of CRF rate was best described by quadratic equations for all four CRF longevities tested (Table 1) with a clear optimum (Table 2 ) beyond which DW decreased. Fertilizer rate accounted for $35 \%, 66 \%, 57 \%$, and $74 \%$ of the variation in shoot DW for 3-4, 5-6, 8-9, and 12-14 months, respectively (Table 1). The maximum predicted DWs were achieved at fertilizer rates of 5.8, $4.7,8.4$, or $11.5 \mathrm{~kg} \cdot \mathrm{m}^{-3}$ for CRF longevities of $3-4,5-6,8-9$, or $12-14$ months, respectively (Table 2 ). Predicted maximum DWs increased with CRF longevity.

At $1.4 \mathrm{~kg} \cdot \mathrm{m}^{-3}$, all CRF treatments yielded significantly lower DWs (23\% to $47 \%$ ) than WSF treatments (Table 1 ). CRF of 12- to 14-month longevity applied at a rate of $1.4 \mathrm{~kg} \cdot \mathrm{m}^{-3}$ produced plants with $31 \%$ less DW than the same rate of the 5- to 6-month longevity fertilizer (Table 1). Plants fertilized with 5 - to 6 -month or 8- to 9 -month fertilizers at a rate of $3.4 \mathrm{~kg} \cdot \mathrm{m}^{-3}$ produced higher DWs than those fertilized at the same rate with 12 - to 14month fertilizer. DW did not differ between plants grown with either WSF or CRF at $6.8 \mathrm{~kg} \cdot \mathrm{m}^{-3}$. At the rate of $10.2 \mathrm{~kg} \cdot \mathrm{m}^{-3}$, DW was significantly lower with the 3- to 4-month fertilizer than the other fertilizers except the 5- to 6-month fertilizer treatment. When CRF was applied at $13.6 \mathrm{~kg} \cdot \mathrm{m}^{-3}$, the 12 - to 14 -month fertilizer produced higher DWs than all other treatments.

Significant differences in LCC were detected at all fertilizer rates except $6.8 \mathrm{~kg} \cdot \mathrm{m}^{-3}$ (Table 1). LCC response to fertilizer rate resembled the response of shoot DW except for plants grown with 12- to 14-month fertilizer (Tables 1 and 2). WSF grown plants had $37 \%$ to $51 \%$ greater LCC than plants from all CRF treatments applied at the rate of $1.4 \mathrm{~kg} \cdot \mathrm{m}^{-3}$. At CRF rate of $3.4 \mathrm{~kg} \cdot \mathrm{m}^{-3}$, WSF plants had greater LCC than those treated with 8 to 9 month and 12- to 14-month fertilizers but had similar LCC as those grown with faster release rates. When CRF was applied at $6.8 \mathrm{~kg} \cdot \mathrm{m}^{-3}$, plants in all treatments had similar LCCs. However, at a rate of $10.2 \mathrm{~kg} \cdot \mathrm{m}^{-3}, 3$ - to 4 month and 5- to 6-month CRFs had a smaller LCC compared with the other treatments. For CRF applied at $13.6 \mathrm{~kg} \cdot \mathrm{m}^{-3}$, the 3 - to 4 -month, 5 - to 6-month, and 8- to 9-month longevities had smaller LCC than 12- to 14month longevity WSF-1 and WSF-2.

The response of $\mathrm{FC}$ as a function of fertilizer rate was significant for

Table 1. Shoot dry weight (DW), leaf canopy cover (LCC), and flower cover (FC) of impatiens plants grown with watersoluble fertilizer (WSF) or controlled-release fertilizers (CRFs) of different longevities (mo.) during Expt. 1. The models describe the rate response of each CRF longevity. Plants were grown with CRF of 3-4, 5-6, 8-9, or 12-14 mo. longevities incorporated at rates of $1.4,3.4,6.8,10.2$, or $13.6 \mathrm{~kg} \cdot \mathrm{m}^{-3}$, or $150 \mathrm{ppm}\left(\mathrm{mg} \cdot \mathrm{L}^{-1}\right)$ nitrogen of a WSF applied at the same volume of water as for CRF (WSF-1) or using a hose (WSF-2). Values are means of six replications.

\begin{tabular}{|c|c|c|c|c|c|c|c|}
\hline \multirow[b]{2}{*}{ Treatments } & \multicolumn{5}{|c|}{ CRF rate $\left(\mathrm{kg} \cdot \mathrm{m}^{-3}\right)^{\mathrm{z}}$} & \multirow[b]{2}{*}{ Model } & \multirow[b]{2}{*}{$R^{2 \mathrm{y}}$} \\
\hline & 1.4 & 3.4 & 6.8 & 10.2 & 13.6 & & \\
\hline \multicolumn{8}{|c|}{ Shoot $D W(g)^{z}$} \\
\hline $5-6 \mathrm{mo}$ & $2.25 \mathrm{~b}$ & $3.53 \mathrm{a}$ & $3.22 \mathrm{a}$ & $2.30 \mathrm{bc}$ & $1.33 \mathrm{e}$ & $y=2.06+0.56 x-0.06 x^{2}$ & 0.66 \\
\hline $8-9$ mo. & $1.75 \mathrm{bc}$ & $3.18 \mathrm{ab}$ & $3.58 \mathrm{a}$ & $3.33 \mathrm{a}$ & $2.33 \mathrm{~cd}$ & $y=1.1+0.67 x-0.04 x^{2}$ & 0.57 \\
\hline 12-14 mo. & $1.58 \mathrm{c}$ & $2.48 \mathrm{c}$ & $3.77 \mathrm{a}$ & $3.52 \mathrm{a}$ & $3.93 \mathrm{a}$ & $y=0.96-0.53 x+0.023 x^{2}$ & 0.74 \\
\hline Significance ${ }^{v}$ & $* * *$ & * & NS & ** & $* * *$ & & \\
\hline \multicolumn{8}{|c|}{$\operatorname{LCC}\left(\mathrm{cm}^{2}\right)^{u}$} \\
\hline $3-4$ mo. & $413 \mathrm{~b}$ & $556 \mathrm{abc}$ & $597 \mathrm{a}$ & $424 \mathrm{~b}$ & $406 \mathrm{bc}$ & $y=387.9+49.9 x-3.7 x^{2}$ & 0.24 \\
\hline $5-6$ mo. & $398 \mathrm{~b}$ & $590 \mathrm{ab}$ & $547 \mathrm{a}$ & $483 \mathrm{~b}$ & $328 \mathrm{c}$ & $y=354.9+66.1 x-5.1 x^{2}$ & 0.51 \\
\hline 8-9 mo. & $350 \mathrm{~b}$ & $511 \mathrm{bc}$ & $664 \mathrm{a}$ & $662 \mathrm{a}$ & $498 \mathrm{~b}$ & $y=202.2+114.3 x-6.6 x^{2}$ & 0.57 \\
\hline Significance & $* * *$ & $* *$ & NS & $* *$ & $* * *$ & & \\
\hline \multicolumn{8}{|c|}{$F C\left(\mathrm{~cm}^{2}\right)^{u}$} \\
\hline $3-4$ mo. & $179 \mathrm{a}$ & $187 \mathrm{a}$ & $123 \mathrm{a}$ & $43 \mathrm{~b}$ & $41 \mathrm{c}$ & $y=218.4-16.7 x+0.2 x^{2}$ & 0.75 \\
\hline $5-6$ mo. & $182 \mathrm{a}$ & $122 \mathrm{a}$ & $75 \mathrm{a}$ & $46 \mathrm{~b}$ & $14 \mathrm{c}$ & $y=208.8-24.15 x+0.81 \mathrm{x}^{2}$ & 0.86 \\
\hline $8-9$ mo. & $193 \mathrm{a}$ & $153 \mathrm{a}$ & $140 \mathrm{a}$ & $133 \mathrm{a}$ & $67 \mathrm{~b}$ & $y=187.3-4.0 x-0.3 x^{2}$ & 0.47 \\
\hline 12-14 mo. & $163 \mathrm{ab}$ & $156 \mathrm{a}$ & $139 \mathrm{a}$ & $121 \mathrm{a}$ & $104 \mathrm{a}$ & NS & $\mathrm{n} / \mathrm{a}$ \\
\hline WSF-1 & $132 \mathrm{~b}$ & $132 \mathrm{a}$ & $132 \mathrm{a}$ & $132 \mathrm{a}$ & $132 \mathrm{a}$ & $\mathrm{n} / \mathrm{a}$ & $\mathrm{n} / \mathrm{a}$ \\
\hline WSF-2 & $129 \mathrm{~b}$ & $129 \mathrm{a}$ & $129 \mathrm{a}$ & $129 \mathrm{a}$ & $129 \mathrm{a}$ & $\mathrm{n} / \mathrm{a}$ & $\mathrm{n} / \mathrm{a}$ \\
\hline Significance & * & NS & NS & $* * *$ & $* * *$ & & \\
\hline
\end{tabular}

${ }^{\mathrm{z}} \mathrm{l} \mathrm{kg} \cdot \mathrm{m}^{-3}=1.6856 \mathrm{lb} /$ yard $^{3}, 1 \mathrm{~g}=0.0353 \mathrm{oz}$.

yCoefficient of determination.

${ }^{x}$ Means with the same letter in a column are not significantly different according to Fisher's least significant difference test at $P \leq 0.05$.

"WSF results are repeated at each CRF rate for comparison purposes.

${ }^{\mathrm{n}} \mathrm{n} / \mathrm{a}, \mathrm{NS},{ }^{*},{ }^{* *}$, or ${ }^{* * *}$ Nonapplicable, nonsignificant, or significant at $P \leq 0.05,0.001$, or 0.0001 , respectively.

"LCC and FC were the results of analyzing pictures taken from above the plants with a special software that measured the exposed leaf area and the exposed area covered by flowers; $1 \mathrm{~cm}^{2}=0.1550$ inch $^{2}$. 
Table 2. Predicted maximum shoot dry weight (DW), leaf canopy cover (LCC), flower cover (FC), consumer ratings of impatiens plants, and their respective fertilizer rates for different controlled-release fertilizer (CRF) longevities (mo.) during Expts. 1 and 2. Plants were grown with CRFs of 3-4, 5-6, 8-9, or 12-14 mo. longevities incorporated at rates of 1.4, 3.4, $6.8,10.2$, or $13.6 \mathrm{~kg} \cdot \mathrm{m}^{-3}$.

\begin{tabular}{|c|c|c|c|c|}
\hline \multirow[t]{2}{*}{ CRF longevity (mo.) } & \multicolumn{2}{|l|}{ Expt. 1} & \multicolumn{2}{|c|}{ Expt. 2} \\
\hline & $\begin{array}{l}\text { Predicted maximum shoot } \\
\text { DW }(\mathrm{g})^{\mathrm{z}}\end{array}$ & $\begin{array}{l}\text { Calculated optimum } \\
\text { CRF rate }\left(\mathrm{kg} \cdot \mathrm{m}^{-3}\right)^{\mathrm{z}}\end{array}$ & $\begin{array}{l}\text { Predicted maximum } \\
\text { shoot } \mathrm{DW}(\mathrm{g})\end{array}$ & $\begin{array}{l}\text { Calculated optimum } \\
\text { CRF rate }\left(\mathrm{kg} \cdot \mathrm{m}^{-3}\right)\end{array}$ \\
\hline $5-6$ & 3.4 & 4.7 & 7.1 & 8.2 \\
\hline $8-9$ & 3.9 & 8.4 & 8.6 & 10.2 \\
\hline $12-14$ & 4.1 & 11.5 & 8.2 & 11.2 \\
\hline $3-4$ & 556.1 & $6.7^{\circ}$ & 1058.2 & 7.9 \\
\hline $5-6$ & 570.0 & 6.5 & 1093.8 & 9.7 \\
\hline $8-9$ & 697.1 & 8.7 & 1223.4 & 11.9 \\
\hline \multirow[t]{2}{*}{$12-14$} & 792.4 & 16.3 & 1186.1 & 12.7 \\
\hline & $\begin{array}{l}\text { Predicted maximum } \\
\text { FC }\left(\mathrm{cm}^{2}\right)\end{array}$ & $\begin{array}{l}\text { Calculated optimum } \\
\text { CRF rate }\left(\mathrm{kg} \cdot \mathrm{m}^{-3}\right)\end{array}$ & $\begin{array}{l}\text { Predicted maximum } \\
\text { FC }\left(\mathrm{cm}^{2}\right)\end{array}$ & $\begin{array}{l}\text { Calculated optimum } \\
\text { CRF rate }\left(\mathrm{kg} \cdot \mathrm{m}^{-3}\right)\end{array}$ \\
\hline $8-9$ & 3.7 & 5.5 & $\mathrm{n} / \mathrm{a}$ & $\mathrm{n} / \mathrm{a}$ \\
\hline $12-14$ & $\mathrm{n} / \mathrm{a}$ & $\mathrm{n} / \mathrm{a}$ & $\mathrm{n} / \mathrm{a}$ & $\mathrm{n} / \mathrm{a}$ \\
\hline
\end{tabular}

Predicted maximum consumer Calculated optimum Predicted maximum consumer Calculated optimum

\begin{tabular}{ccccc} 
& CRF rate $\left(\mathbf{k g} \cdot \mathbf{m}^{-\mathbf{3}}\right)$ & rating $(\mathbf{1}-\mathbf{5}$ scale $)$ & \\
$3-4$ & 3.3 & 6.0 & 3.4 & \\
$5-6$ & 3.3 & 5.5 & 4.0 & 10.0 \\
$8-9$ & 3.7 & 5.5 & $\mathrm{n} / \mathrm{a}$ & $\mathrm{n} / \mathrm{a}$ \\
$12-14$ & $\mathrm{n} / \mathrm{a}$ & $\mathrm{n} / \mathrm{a}$ & $\mathrm{n} / \mathrm{a}$ & $\mathrm{n} / \mathrm{a}$ \\
\hline
\end{tabular}

${ }^{2} 1 \mathrm{~kg} \cdot \mathrm{m}^{-3}=1.6856 \mathrm{lb} / \mathrm{yard}^{3} ; 1 \mathrm{~g}=0.0353 \mathrm{oz}$.

'LCC and FC were the results of analyzing pictures taken from above the plants with a special software that measured the exposed leaf area and the exposed area covered by flowers; $1 \mathrm{~cm}^{2}=0.1550 \mathrm{inch}^{2}$.

${ }^{x}$ Not applicable.

${ }^{w}$ Consumer ratings with 1 indicating the reviewer disliked the plant and 5 indicating the reviewer liked the plant very much.

three of the four longevities tested (Table 1 ). With the exception of 12 to 14-month longevity fertilizer, increasing rates resulted in smaller FCs, which represent fewer or smaller flowers (Table 1 ). At the rate of $1.4 \mathrm{~kg} \cdot \mathrm{m}^{-3}$, CRF plants (except 12- to 14-month longevity CRF-treated plants) had 27\% to $32 \%$ larger FC than WSF plants (Table 1). There were no significant differences in FC between treatments when CRF was applied at rates of 3.4 or $6.8 \mathrm{~kg} \cdot \mathrm{m}^{-3}$. Flowers from 3- to 4 month and 5- to 6-month CRF applications at rates of 10.2 or $13.6 \mathrm{~kg} \cdot \mathrm{m}^{-3}$ covered a smaller portion of the plant canopy than the other treatments. For responses that were significant, fertilizer rates explained $75 \%, 86 \%$, and $47 \%$ of the variation in FC for the 3- to 4month, 5- to 6-month, and 8- to 9month fertilizer longevities, respectively (Table 1).

There were significant differences in consumer ratings of plants from all longevities with the exception of those grown with $3.4 \mathrm{~kg} \cdot \mathrm{m}^{-3} \mathrm{CRF}$ application rate (Table 3 ). When CRF was applied at $1.4 \mathrm{~kg} \cdot \mathrm{m}^{-3}$, consumers preferred WSF plants over CRF treatments except the 12- to 14-month longevity treated plants. At CRF application rate of $6.8 \mathrm{~kg} \cdot \mathrm{m}^{-3}, 3$ - to 4 -month longevity treated plants received lower scores than the other treatments except for 5- to 6-month longevity treated plants. The 3- to 4-month and 5- to 6-month longevities at rates of $10.2 \mathrm{~kg} \cdot \mathrm{m}^{-3}$ had the lowest rating. At the $13.6 \mathrm{~kg} \cdot \mathrm{m}^{-3}$ rate, the consumers preferred the 12- to 14-month treated plants and WSF plants over other treatments. Significant responses of consumer ratings as a function of application rate were detected for all CRF longevities except the 12- to 14month treatment (Table 3). Maximum predicted consumer ratings of 3.3, 3.3 , and 3.7 were obtained at $6.0,5.5$, and $5.5 \mathrm{~kg} \cdot \mathrm{m}^{-3}$ for the 3 - to 4 -month, 5- to 6-month, and 8- to 9-month longevity treated plants, respectively
(Table 2). It should be noted that although significant, rate of application explained only a small part $(10 \%$ to $22 \%$ ) of the variation in consumer preference (Table 3 ).

Expт. 2. Similar to Expt. 1, shoot DWs as a function of application rates were best described by quadratic equations (Table 4) and predicted shoot DW (Table 2) increased with increasing fertilizer rates up to a maximum that was dependent on longevity or release rate. Maximum DWs were predicted to occur at fertilizer rates of $8.0,8.2,10.2$, or $11.2 \mathrm{~kg} \cdot \mathrm{m}^{-3}$ for $3-$ to 4 -month, 5- to 6-month, 8- to 9month, or 12- to 14-month longevity treatments, respectively (Table 2). CRF rate explained $65 \%, 61 \%, 85 \%$, and $93 \%$ of the variation in shoot DW for 3- to 4-month, 5- to 6month, 8- to 9-month, and 12- to 14-month longevity treatments, respectively. The increasing trend of predicted maximum DW with increasing CRF rates of applications was less 
Table 3. Consumer ratings of impatiens plants obtained during Expts. 1 and 2. The models describe the rate response of each controlled-release fertilizer (CRF) longevity. Plants were grown with CRF of 3-4, 5-6, 8-9, or 12-14 mo. longevities incorporated at rates of $1.4,3.4,6.8,10.2$, or $13.6 \mathrm{~kg} \cdot \mathrm{m}^{-3}$, or with a water-soluble fertilizer (WSF) at $150 \mathrm{ppm}\left(\mathrm{mg} \cdot \mathrm{L}^{-1}\right)$ nitrogen applied at the same volume of water as for CRF (WSF-1) or using a hose (WSF-2). Values are means of 40 (Expt. 1 ) or 35 (Expt. 2) ratings.

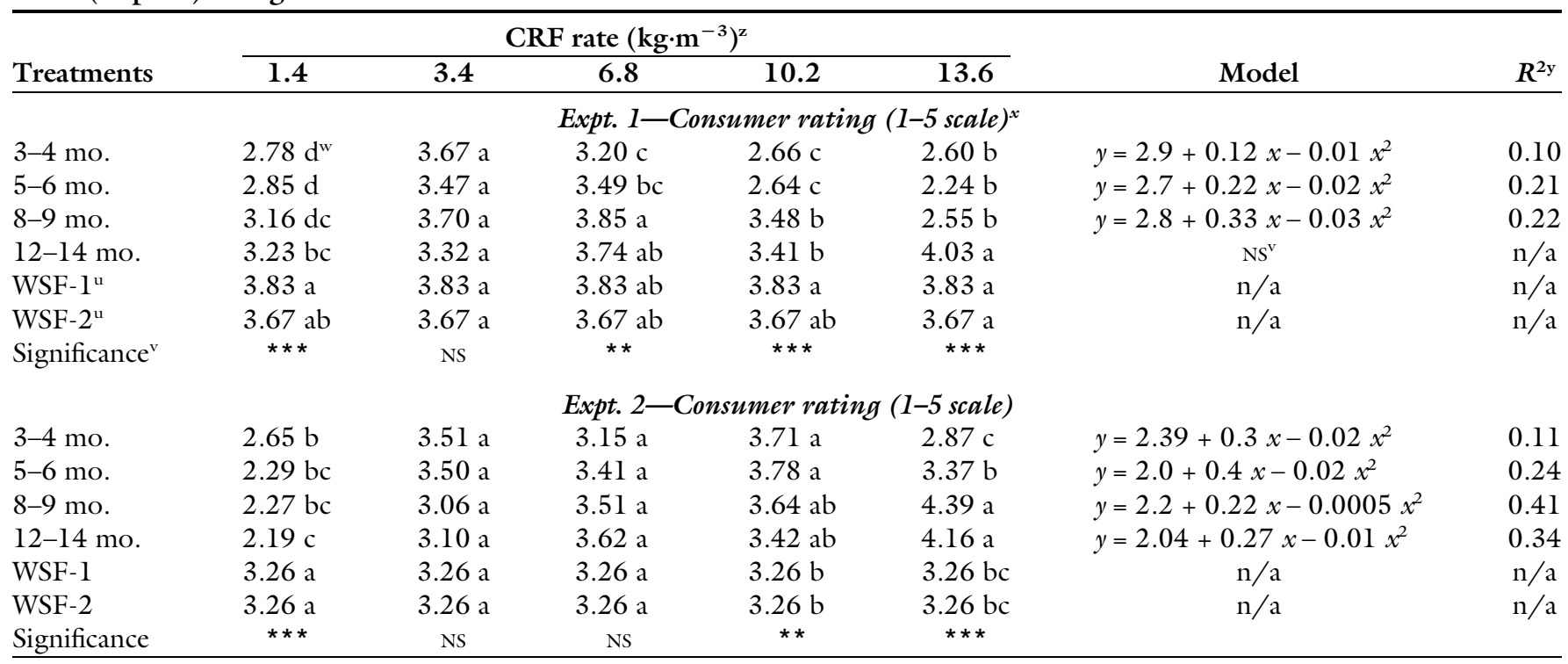

${ }^{\mathrm{z}} 1 \mathrm{~kg} \cdot \mathrm{m}^{-3}=1.6856 \mathrm{lb} / \mathrm{yard}^{3}$

yCoefficient of determination.

${ }^{\mathrm{x}}$ Consumer ratings with 1 indicating the reviewer disliked the plant and 5 indicating the reviewer liked the plant very much.

"Means with the same letter in a column are not significantly different according to Fisher's least significant difference (LSD) test at $P \leq 0.05$.

${ }^{\mathrm{N} S}, \mathrm{n} / \mathrm{a},{ }^{* *}$, or ${ }^{* * *}$ Nonsignificant, not applicable, or significant according to Fisher's LSD test at $P \leq 0.001$ or 0.0001 , respectively.

${ }^{u}$ WSF results are repeated at each CRF rate for comparison purposes.

clear than in Expt. 1 but still noticeable (Table 2).

There were significant differences among fertilizer types in shoot DW at fertilizer application rates of $1.4,3.4$, and $13.6 \mathrm{~kg} \cdot \mathrm{m}^{-3}$ (Table 4 ). DWs of WSF-treated plants were higher than CRF-treated plants for all longevities tested at rates of 1.4 and $3.4 \mathrm{~kg} \cdot \mathrm{m}^{-3}$. At the highest CRF rate $\left(13.6 \mathrm{~kg} \cdot \mathrm{m}^{-3}\right)$, the 3- to 4-month longevity fertilizer produced plants with the lowest DW.

Significant differences in LCC and FC were found in plants treated with the $1.4,3.4$, and $13.6 \mathrm{~kg} \cdot \mathrm{m}^{-3}$ application rates (Table 4 ). When CRF was applied at rates of 1.4 or $3.4 \mathrm{~kg} \cdot \mathrm{m}^{-3}$, the LCC of CRF-treated plants was smaller than that of WSF plants. When CRF was applied at $13.6 \mathrm{~kg} \cdot \mathrm{m}^{-3}$, the 3 - to 4-month and 5- to 6-month longevity treatments had the smallest LCC. LCC was similar for all longevities when CRF was applied at 6.8 or $10.2 \mathrm{~kg} \cdot \mathrm{m}^{-3}$. Quadratic models best described the response of LCC as a function of application rates (Table 4). A trend of increasing predicted maximum LCC was observed with increasing CRF application rates (Table 2). The predicted maximum LCCs occurred at $7.9,9.7,11.9$, and $12.7 \mathrm{~kg} \cdot \mathrm{m}^{-3} \mathrm{ap}-$ plication rates for the 3- to 4 -month,
5- to 6-month, 8- to 9-month, and 12- to 13-month longevities, respectively (Table 2 ). Fertilizer rates explained $54 \%, 58 \%, 89 \%$, and $92 \%$ of the LCC variation for the 3- to 4month, 5- to 6-month, 8- to 9-month, and 12-to 14-month longevity fertilizers, respectively (Table 4 ).

At CRF rates of $1.4 \mathrm{~kg} \cdot \mathrm{m}^{-3}$, WSF- 1 and WSF-2 treated plants had smaller FCs than 3- to 4-month longevity CRF-treated plants (Table 4). When CRF was applied at $3.4 \mathrm{~kg} \cdot \mathrm{m}^{-3}$, the 5 to 6-month and 12- to 14-month longevities had higher FC than either WSF-treated plants. All plants had similar FC at CRF rates of 6.8 and $10.2 \mathrm{~kg} \cdot \mathrm{m}^{-3}$. FC of 8 - to 9 -month and 12- to 14-month longevity CRF treatments was greater than the other treatments when the CRF was applied at $13.6 \mathrm{~kg} \cdot \mathrm{m}^{-3}$. No significant effect of CRF rate of application on FC was found in Expt. 2.

At a $1.4 \mathrm{~kg} \cdot \mathrm{m}^{-3}$ rate of application, consumers preferred the WSF plants over the CRF-treated plants (Table 3 ). At this same rate, 3 - to 4-month longevity fertilizer plants received a higher rating than 12 - to 14 month fertilizer plants. When CRF were applied at $10.2 \mathrm{~kg} \cdot \mathrm{m}^{-3}$, consumer ratings for 3- to 4-month and 5- to 6-month longevity treated plants were higher than WSF plants. The 8- to 9month and 12 to 14 -month longevity treatments at rates of $13.6 \mathrm{~kg} \cdot \mathrm{m}^{-3}$ received a higher score than the other treatments.

Predicted consumer rating increased with increasing rates of application up to a maximum and then decreased for the 3-to 4-month and 5- to 6-month longevity treatments (Table 2). These predicted maximums occurred at 7.5 and $10 \mathrm{~kg} \cdot \mathrm{m}^{-3}$, respectively. No predicted maximum was obtained for the 8- to 9-month and 12- to 14-month longevity fertilizers. Again, fertilizer rates explained only a small part $(11 \%-41 \%)$ of the variation in consumer ratings (Table 3 ).

\section{Discussion}

The general patterns observed strongly suggest that at low application rates, greater longevity CRFs release insufficient nutrients to meet the demands of rapidly growing crops early in the season. At higher application rates, release by shorter longevity CRF may result in excessive EC, as shown in a single sample of EC in relation to treatments (Fig. 1), chronic toxicities, or both. At low fertilizer application rates, the faster release rate 
Table 4. Shoot dry weight (DW), leaf canopy cover (LCC), and flower cover (FC) of impatiens plants from Expt. 2 grown with water-soluble fertilizer (WSF) or controlled-release fertilizer (CRF). The models describe the rate responses of each CRF longevity (mo.). Plants were grown with CRF of 3-4, 5-6, 8-9, or 12-14 mo. longevities incorporated at rates of 1.4, 3.4, $6.8,10.2$, or $13.6 \mathrm{~kg} \cdot \mathrm{m}^{-3}$, or $150 \mathrm{ppm}\left(\mathrm{mg} \cdot \mathrm{L}^{-1}\right)$ nitrogen of WSF applied at the same volume of water as for CRF (WSF-1) or using a hose (WSF-2). Values are means of six replications.

\begin{tabular}{|c|c|c|c|c|c|c|c|}
\hline \multirow[b]{2}{*}{ Treatments } & \multicolumn{5}{|c|}{ CRF rate $\left(\mathrm{kg} \cdot \mathrm{m}^{-3}\right)^{\mathrm{z}}$} & \multirow[b]{2}{*}{ Model } & \multirow[b]{2}{*}{$R^{2 \mathrm{y}}$} \\
\hline & 1.4 & 3.4 & 6.8 & 10.2 & 13.6 & & \\
\hline \multicolumn{8}{|c|}{ Shoot $D W(g)^{z}$} \\
\hline 3-4 mo. & $3.23 b^{x}$ & $5.79 \mathrm{bc}$ & $6.68 \mathrm{a}$ & $7.04 \mathrm{a}$ & $4.15 \mathrm{c}$ & $y=1.53+1.45 x-0.09 x^{2}$ & 0.65 \\
\hline $5-6$ mo. & $3.43 \mathrm{~b}$ & $6.21 \mathrm{~b}$ & $6.82 \mathrm{a}$ & $6.88 \mathrm{a}$ & $5.62 \mathrm{~b}$ & $y=2.35+1.15 x-0.07 x^{2}$ & 0.61 \\
\hline $8-9$ mo. & $2.60 \mathrm{~cd}$ & $5.37 \mathrm{~cd}$ & $7.46 \mathrm{a}$ & $7.49 \mathrm{a}$ & $7.51 \mathrm{a}$ & $y=1.16+1.34 x-0.06 x^{2}$ & 0.85 \\
\hline 12-14 mo. & $2.33 \mathrm{~d}$ & $4.62 \mathrm{~d}$ & $6.75 \mathrm{a}$ & $7.85 \mathrm{a}$ & $7.25 \mathrm{a}$ & $y=0.63+1.35 x-0.06 x^{2}$ & 0.93 \\
\hline Significance $^{\mathrm{v}}$ & $* * *$ & $* * *$ & NS & NS & $* * *$ & & \\
\hline \multicolumn{8}{|c|}{$\operatorname{LCC}\left(\mathrm{cm}^{2}\right)^{u}$} \\
\hline $3-4$ mo. & $568 \mathrm{~b}$ & $865 c$ & $762 \mathrm{a}$ & $1079 \mathrm{a}$ & $677 \mathrm{~d}$ & $y=346.2+179.4 x-11.3 x^{2}$ & 0.54 \\
\hline $5-6$ mo. & $533 \mathrm{bc}$ & 994 bc & $964 a$ & 1079 a & $991 \mathrm{c}$ & $y=425.2+137.8 x-7.1 x^{2}$ & 0.58 \\
\hline $8-9$ mo. & $452 \mathrm{c}$ & $711 \mathrm{~d}$ & $1116 \mathrm{a}$ & $1123 \mathrm{a}$ & $1233 \mathrm{a}$ & $y=243.0+164.5 x-6.9 x^{2}$ & 0.89 \\
\hline \multicolumn{8}{|c|}{$F C\left(\mathrm{~cm}^{2}\right)^{u}$} \\
\hline $3-4$ mo. & 390 a & 399 ba & $313 \mathrm{a}$ & $301 \mathrm{a}$ & $140 \mathrm{~b}$ & NS & $\mathrm{n} / \mathrm{a}$ \\
\hline $5-6$ mo. & $283 \mathrm{abc}$ & 508 a & $244 \mathrm{a}$ & 292 a & $157 \mathrm{~b}$ & NS & $\mathrm{n} / \mathrm{a}$ \\
\hline $8-9$ mo. & $275 \mathrm{abc}$ & $351 \mathrm{abc}$ & $354 \mathrm{a}$ & $415 \mathrm{a}$ & $506 a$ & NS & $\mathrm{n} / \mathrm{a}$ \\
\hline 12-14 mo. & 297 ba & 458 a & $440 \mathrm{a}$ & 406 a & $480 \mathrm{a}$ & NS & $\mathrm{n} / \mathrm{a}$ \\
\hline WSF-1 & $170 \mathrm{c}$ & $170 \mathrm{c}$ & $170 \mathrm{a}$ & $170 \mathrm{a}$ & $170 \mathrm{~b}$ & $\mathrm{n} / \mathrm{a}$ & $\mathrm{n} / \mathrm{a}$ \\
\hline WSF-2 & 249 bc & 249 bc & $249 \mathrm{a}$ & $249 \mathrm{a}$ & $249 \mathrm{~b}$ & $\mathrm{n} / \mathrm{a}$ & $\mathrm{n} / \mathrm{a}$ \\
\hline Significance & * & ** & NS & NS & $* * *$ & & \\
\hline
\end{tabular}

${ }^{\mathrm{z}} 1 \mathrm{~kg} \cdot \mathrm{m}^{-3}=1.6856 \mathrm{lb} /$ yard $^{3} ; 1 \mathrm{~g}=0.0353 \mathrm{oz}$.

${ }^{y}$ Coefficient of determination.

${ }^{x}$ Means with the same letter in a column are not significantly different according to Fisher's least significant difference (LSD) test at $P \leq 0.05$.

"WSF results are repeated at each CRF rate for comparison purposes.

${ }^{\mathrm{n}} \mathrm{n} / \mathrm{a}, \mathrm{Ns},{ }^{*},{ }^{* *}$, or ${ }^{* * *}$ Nonapplicable, nonsignificant, or significant at $P \leq 0.05,0.001$, or 0.0001 , respectively.

"LCC and FC were the results of analyzing pictures taken from above the plants with a special software that measured the exposed leaf area and the exposed area covered by flowers; $1 \mathrm{~cm}^{2}=0.1550$ inch $^{2}$.

(shorter longevities) CRF produced larger plants (DW and LCC) with greater flowering potential (FC). At higher application rates, slower release rates (longer longevities) outperformed the faster release CRF for the same parameters. This was consistent with the recommended rates of the fertilizer where the optimal application rate for a longer longevity CRF was higher than the rate for a fertilizer of shorter longevity. Even though longevity of a CRF can be affected by cultural practices, growing environment, and substrate temperature (Hulme and Buchheit, 2007; Scotts Company, 2005 ), in these two experiments, relative responses were clear: when low rates were applied, a short longevity CRF supplied sufficient nutrition while this was achieved with higher rates of fertilizers of greater longevities. Larger maximum DWs obtained with CRF of greater longevities may be explained as these fertilizers providing a small but continuous availability of nutrients during the whole crop cycle.

Plants grown at a CRF rate of $1.4 \mathrm{~kg} \cdot \mathrm{m}^{-3}$ (Expts. 1 and 2 ) and $3.4 \mathrm{~kg} \cdot \mathrm{m}^{-3}$ (Expt. 1) had smaller LCCs than WSF plants, probably because of lower nutrient levels. Stunting of plants grown with low fertilizer rates $\left(1.4 \mathrm{~kg} \cdot \mathrm{m}^{-3}\right)$ in our work was similar to results presented by Parks et al. (2007). They grew six species of the protea family (Proteaceae) with different rates of Osmocote CRF and found that plants grown with fertilizer rates of $1.25 \mathrm{~kg} \cdot \mathrm{m}^{-3}$ were stunted.

On the other hand, plants fertilized with CRF of shorter longevity (3-4 and 5-6 months) and higher rates of either 10.2 (Expts. 1 and 2) or $13.6 \mathrm{~kg} \cdot \mathrm{m}^{-3}$ (Expt. 2) had smaller
LCCs and FCs than the other treatments perhaps due to an excess of salts. Plants grown with high nutrient levels may take longer time to mature perhaps due to salt stress and time to adapt to high substrate EC (Haver and Schuch, 1996). Our results were similar to those of Haver and Schuch (1996), who found that new guinea impatiens (Impatiens hawkeri 'Illusion') grown with either low $\left(4.5 \mathrm{~kg} \cdot \mathrm{m}^{-3}\right)$ or high $\left(13.5 \mathrm{~kg} \cdot \mathrm{m}^{-3}\right)$ CRF rates had marketable quality but lacked the stature and fullness of plants grown with $8.9 \mathrm{~kg} \cdot \mathrm{m}^{-3}$, which in this case was a medium rate. The $6.8 \mathrm{~kg} \cdot \mathrm{m}^{-3}$ can be considered the "universal" rate of application for the studied cultivar since this rate with all longevities in Expts. 1 and 2 (different environmental conditions) produced plants of similar shoot DWs, LCCs, and FCs. The extent of the differences and 


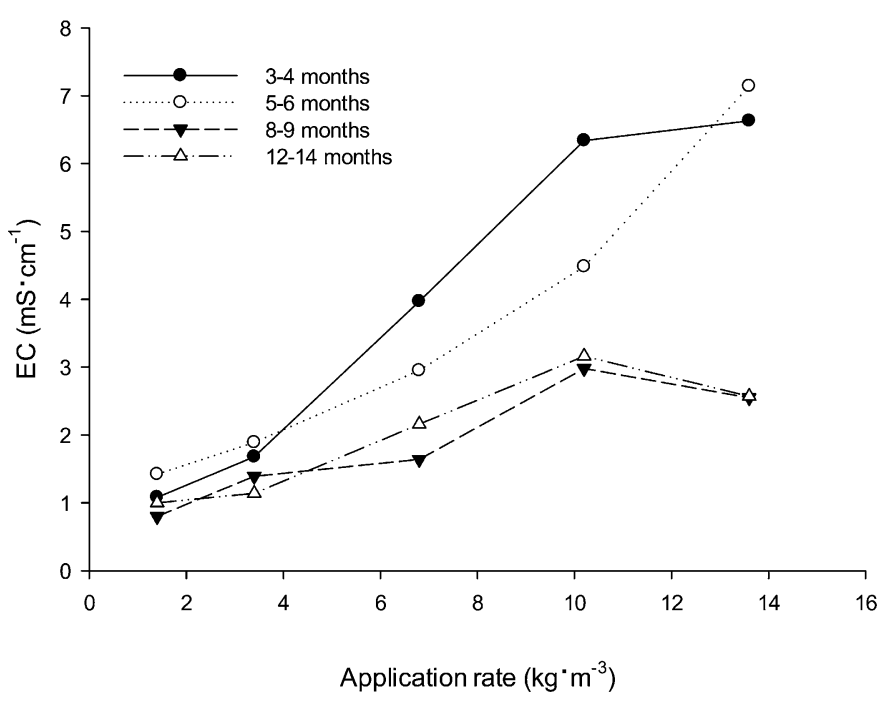

Fig. 1. Electrical conductivity (EC) as a function of controlled-release fertilizer application rates $7 \mathrm{~d}$ after planting impatiens plugs. Substrate EC of the watersoluble fertilizer-treated plant (WSF-1) was $1.1 \mathrm{mS} \cdot \mathrm{cm}^{-1}$. Values were obtained from a single replicate plant from each treatment using the pour-through method (Cavins et al., 2001); $1 \mathrm{mS} \cdot \mathrm{cm}^{-1}=1 \mathrm{mmho} / \mathrm{cm}, 1 \mathrm{~kg} \cdot \mathrm{m}^{-3}=1.6856 \mathrm{lb} / \mathrm{yard}^{3}$.

absolute size of the plants depended on the experiment because of environmental differences encountered in the two time periods. Expt. I was performed in the fall and winter with a DLI of $6.5 \mathrm{~mol} \cdot \mathrm{m}^{-2} \cdot \mathrm{d}^{-1}$, far lower than the DLI encountered in Expt. 1, which was performed in the spring and summer $\left(\right.$ DLI $\left.=18.2 \mathrm{~mol} \cdot \mathrm{m}^{-2} \cdot \mathrm{d}^{-1}\right)$.

WSF is still the preferred method of applying fertilizers to bedding plants. In our experiments, there was little difference resulting from the two WSF application methods, with the exception of FC in Expt. 2. The reduced volume of water to apply the nutrients used in WSF-1 reduced flowering area compared with high leaching rates used for WSF-2. In spite of this difference, consumers indicated no difference in preference between these two treatments. In fact, consumer ratings values among all treatments showed little variation. This is encouraging because it suggests that growers have far more leeway in experimenting with growing techniques that optimize resources (e.g., fertility and water) than currently believed. Greater production efficiencies may be obtained because of the broad range of consumer acceptability demonstrated in this study even when DW, LCC, and FC are treatment dependent. If consumers will only discern extreme differences, optimizing nutrients strategies should focus on the economic and environmental benefits. As a consequence, growers may adopt low nutrient strategies. Furthermore, more research is needed to calibrate grower and consumer expectations of the "perfect plant."

Based on results obtained in these two experiments, it is not possible to explain the high variability (low $R^{2}$ ) observed in shoot DW, LCC, and FC with fertilizers of short longevity. It is important to note, however, that there was a trend in increasing $R^{2}$ for shoot DW and LCC with increasing CRF longevities. CRFs release a substantial amount of nutrients soon after application (Adams et al., 2013; Cox, 1993; Hershey and Paul, 1982; Rathier and Frink, 1989) when plants are young and with a small root system most likely not well distributed in the container. We hypothesize that this results in substantial nutrient losses, uneven absorption by the plants (depending on the location of the fertilizer prills and roots in the container), and, hence, variable plant sizes. On the other hand, longlasting CRF (e.g., 12-14 months) release nutrients slowly over a longer period of time and at a time when roots are grown and well distributed in the container. The consequences are more uniform and complete nutrient absorption in keeping with plant demand, therefore, permitting more uniform plant growth. This hypothesis will be tested in future work.

\section{Conclusions}

The effect of CRF longevity on plant growth characteristics and consumer preferences was a function of fertilizer rate and environmental variables. Shoot DW and LCC were more sensitive to fertilizer rates than FC. Consumer ratings indicated clear preferences for plants grown with CRF of some longevity over others depending on the rate of application. Growers should be aware that adjusting CRF rate of application is necessary when using different longevities. To achieve maximum plant growth, CRF of extended longevities require higher application rates. However, for the cultivar studied, $6.8 \mathrm{~kg} \cdot \mathrm{m}^{-3}$ can be considered the "universal" rate of application for all longevities of an Osmocote 16-3.9-10.0 CRF.

\section{Literature cited}

Adams, C., J. Frantz, and B. Bugbee. 2013. Macro- and micro-nutrient release characteristics of three polymer-coated fertilizer technologies: Theory and measurement. J. Plant Nutr. Soil Sci. (In press).

Andiru, G.A., C.C. Pasian, J.M. Frantz, and M. Jones. 2011. How much water and nitrogen is wasted when a hose is used? OFA Bul. 6(3):17-18.

Argo, W.R. and J.A. Biernbaum. 1996. The effect of lime, irrigation-water source, and water-soluble fertilizer on root-zone $\mathrm{pH}$, electrical conductivity, and macronutrient management of container root media with impatiens. J. Amer. Soc. Hort. Sci. 121:442-452.

Broschat, T.K. and K.A. Klock-Moore. 2001. Influence of substrate and fertilizer analysis and rate on growth and quality of five species of bedding plants. HortTechnology 11:434-437.

Bumgarner, N.R., W.S. Miller, and M.D. Kleinhenz. 2012. Digital image analysis to supplement direct measures of lettuce biomass. HortTechnology 22:547-555.

Cabrera, R.I. 1997. Comparative evaluation of nitrogen release patters from controlled-release fertilizers by nitrogen leaching analysis. HortScience 32:669673.

Cavins, T.J., B.E. Whipker, W.C. Fonteno, and J.L. Gibson. 2001. Greenhouse substrate testing, p. 31-36. In: B.E. Whipker, J.M. Dole, T.J. Cavins, J.L. Gibson, W.C. Fonteno, P.V. Nelson, D.S. Pitchay, and D.A. Bailey (eds.). Plant root zone management. North Carolina Flower Growers' Assn., Raleigh, NC. 
Colangelo, D.J. and M.H. Brand. 2001. Nitrate leaching beneath a containerized nursery crop receiving trickle or overhead irrigation. J. Environ. Qual. 30:15641574.

Cox, D.A. 1993. Reducing nitrogen leaching-loss from containerized plants: The effectiveness of controlled-release fertilizers. J. Plant Nutr. 16:533-545.

Haver, D.L. and U.K. Schuch. 1996. Production and postproduction performance of two new guinea impatiens cultivars grown with controlled-release fertilizer and no leaching. J. Amer. Soc. Hort. Sci. 121:820-825.

Hershey, D.R. and J.L. Paul. 1982. Leaching-losses of nitrogen from pot chrysanthemums with controlled-release or liquid fertilization. Sci. Hort. 17:145-152.

Hulme, F. 2006. Combination fertilizer programs for flowering pot plants: Highlight from the Ohio State University trials. Scotts Exchange Tech. Shares, The Scotts Co., Marysville, $\mathrm{OH}$.

Hulme, F. and C. Buchheit. 2007. The value in Osmocote controlled-release technology. Scotts Exchange Tech. Shares, The Scotts Co., Marysville, $\mathrm{OH}$.
Ivy, R.L., T.E. Bilderback, and S.L. Warren. 2002Date of potting and fertilization affects plant growth, mineral nutrient content, and substrate electrical conductivity J. Environ. Hort. 20:104-109.

Klock-Moore, K.A. and T.K. Broschat. 1999. Differences in bedding plant growth and nitrate loss with a controlled-release fertilizer and two irrigation systems. HortTechnology 9:206-209.

Lamari, L. 2002. Assess image analysis software for plant disease quantification. APS Press, St. Paul, MN.

Medina, L.C., T.A. Obreza, J.B. Sartain, and R.E. Rouse. 2008. Nitrogen release patterns of mixed controlled-release fertilizer and its components. HortTechnology 18:475-480.

Merhaut, D.J., E.K. Blythe, P.J. Newman, and J.P. Albano. 2006. Nutrient release from controlled-release fertilizers in acid substrate in a greenhouse environment: 1 . Leachate electrical conductivity, $\mathrm{pH}$, and nitrogen, phosphorus and potassium concentrations. HortScience 41:780-787.

Nelson, P.V. 1991. Greenhouse operation and management. Prentice Hall, Englewood Cliffs, NJ.
Parks, S.E., A.M. Haigh, and A.M. Harris. 2007. Response of six species of Proteaceae in containers to controlled-release fertilizer. Commun. Soil Sci. Plant Anal. 38:2227-2237.

Rathier, T.M. and C.R. Frink. 1989. Nitrate runoff water from container grown juniper and alberta spruce under different irrigation and $\mathrm{N}$ fertilization regimes. J. Environ. Hort. 7:32-35.

Scotts Company. 2005. Osmocote Plus controlled-release fertilizer. Product fact sheet. Marysville, $\mathrm{OH}$.

Shaviv, A. 2001. Advances in controlledrelease fertilizers. Adv. Agron. 71:1-49.

Simonne, E.H. and C.M. Hutchinson. 2005. Controlled-release fertilizers for vegetable production in the era of best management practices: Teaching new tricks to an old dog. HortTechnology $15: 36-46$.

Wright, R.D. 1992. Researcher's perspective on current and future water quality research. Proceedings of the workshop "Impact of runoff water quality on future nursery crop production." HortTechnology $2: 84$. 